\title{
An Assessment of Information and Records Management Department Students' Perceptions Towards the Use of Distance Learning Tools: Example of Atatürk University
}

\section{Bilgi ve Belge Yönetimi Bölümü Öğrencilerinin Uzaktan Ĕğitim Araçlarının Kullanımına Yönelik Algılarının Değerlendirilmesi: Atatürk Üniversitesi Örneği}

\author{
Malik Y1lmaz $^{1}$ [1), Burcu Aydemir Şenay ${ }^{1}$ [C]
}

${ }^{1}$ Atatürk University, Faculty of Letters, Information and Records Management, Erzurum, Turkey

ORCID: M.Y. 0000-0002-3217-9776; B.A.Ş. 0000-0003-0409-1571

Corresponding author/Sorumlu yazar: Malik Y1lmaz (Asst. Prof.),

Atatürk University, Faculty of Letters,

Information and Records Management, Erzurum, Turkey

E-mail: malik.yilmaz@atauni.edu.tr

Submitted/Bașvuru: 19.11.2020

Revision Requested/Revizyon Talebi: 28.11.2020 Last Revision Received/Son Revizyon: 29.11.2020 Accepted/Kabul: 05.12.2020

Citation/Atıf: Yılmaz, M., \& Aydemir Şenay, B. (2020). An assesment of perceptions of information and records management department students towards the use of distance learning tools: Example of Atatürk University. Bilgi ve Belge Araștırmalart Dergisi, 14, 135-146.

http://doi.org/10.26650/bba.2020.14.05

\begin{abstract}
Rapid developments experienced in information and communication technologies affect the educational field like any other field. One of these field is Information and Records Management where technology must be used effectively. Technology has changed the education provision manner and content considerably and revealed the technology-centered training tendency. Students, enrolled at the Department of Information and Records Management, combine technology literacy and information literacy in the education scope along with the curriculum suggested by the department and are raised as individuals who can use information technologies effectively in their profession Distance education tools are used effectively as educational tools by both educators and students due to the fact that they ensure an opportunity to receive education which is formed physically independent from the educational institution. In this sense, this study aimed to measure the perceptions of The Atatürk University, Faculty of Letters, Department of Information and Records Management students about the use of technologybased distance education tools and to assess how they contributed to their education. For this reason, a survey consisting of 16 questions was applied to determine the perceptions of the students of the Department of Information and Records Management about the use of distance education tools and the results have been evaluated.
\end{abstract}

Keywords: Education, distance education, distance education tools, Atatürk University, students

ÖZ

Bilgi ve iletişim teknolojilerinde yaşanan hızlı gelişmeler her alanı etkilediği gibi eğitim alanını da doğrudan etkilemiş̧tir. Bunlardan biri teknolojinin etkin olarak kullanılması gereken alanlardan olan Bilgi ve Belge Yönetimi'dir. Teknoloji, eğitimin veriliș biçimini ve içeriğini önemli ölçüde değiştirerek teknoloji merkezli eğitim verme eğilimini ortaya çıkarmıştır. Bilgi ve Belge Yönetimi bölümünde eğitim alan öğrenciler, bölüm müfredatının onlara önerdiği ve eğitim kapsamında yer alan teknoloji okuryazarlığını bilgi okuryazarlığı ile birleștirerek mesleki açıdan bilgi teknolojilerini etkin bir şekilde kullanabilecek bireyler olarak yetişmektedir. Uzaktan eğitim araçları öğrenciye fiziksel olarak eğitim kurumundan bağımsız olarak eğitim alma olanağı tanımasından ötürü hem eğitimcilerin hem de öğrencilerin yöneldiği eğitim araçları olarak etkin bir şekilde kullanılmaktadır. Bu bağlamda çalışmada, Bilgi ve Belge Yönetimi öğrencilerinin teknolojik tabanlı uzaktan eğitim araçlarının kullanımına yönelik algılarının ölçülmesi ve eğitimlerine nasıl katkıda bulunduklarının değerlendirilmesi hedeflenmiştir. Bu amaçla Atatürk Üniversitesi Bilgi ve Belge Yönetimi Bölümü ögrencilerine bu araçların kullanımına yönelik algılarını belirlemek için anket yoluyla veriler toplanmıştır. Çalışma kapsamında bu veriler değerlendirilerek söz konusu algı ortaya konulmaya çalıșılmışıtır. Anahtar kelimeler: Eğitim, uzaktan eğitim, uzaktan eğitim araçları, Atatürk Üniversitesi, öğrenciler 


\section{INTRODUCTION}

Doing what is necessary to be an information society is feasible with qualified human power of societies. Qualified human power is needed to accomplish the requirements of information society. This can be achieved by a qualified, efficient, dynamic and interactive educational system. Rapid change and progress experienced in information technologies have affected the educational systems as well. As a consequence of these changes and progresses, face-toface education has started to be inadequate. The individuals who receive education access the international developments occurring in their educational field and new educational techniques by means of the distance education service. Information and communication technologies were used as auxiliary tools in the education field during the 1990s and today, they have affected nearly the entire field and education is provided by these means. Hence, the distance education concept has emerged in parallel to these developments and changes, and education has started to be provided in an electronic setting without meeting physically and being dependent on the physical environment and time.

Due to today's pandemic conditions, distance education and distance education tools have become more important. The students of the Department of Information and Records Management, Atatürk University, Faculty of Letters have been affected by this process as well as other students. That is why in this study the knowledge level of the students in this regard and their perception towards distance education and also distance education tools were examined carefully. Distance learning is considered crucially important for students of the departments of Information and Records Management in particular due to the fact that this process will affect their professional roles in the future, along with the skills? needed to adapt the changes.

\section{Distance Education}

Distance education is a service which provides educational activities for students in various settings without time and place limitations by means of information and technology-based tools including internet and computer software. In other words, distance education can be defined as a learning method for the continuation of education by using technological tools in situations where face-to-face educational techniques and/or activities are difficult to carry out (Şenay et al., 2015). Another definition of distance education is "A form of education in which the main elements include physical separation of teachers and students during instruction and the use of various technologies to facilitate student-teacher and student-student communication" (Distance learning, 2012; Tang, 2013, p. 500).

It is stated that the developments regarding the concept of distance education date back to the 1700 s with the steno lessons of the Boston newspaper in 1728. Following this, in 1833, composition lessons by letter began to be given in Sweden. In 1840, Pitman began to teach 
steno by letter. The practice of letter education, which was first started by the University of Chicago in 1892, then continued with language education in Sweden, and in the early 1990s, the development continued with radios used for distance education in the United States. In 1932, television education started at IOWA University. In 1960, British Open University was opened in England. In our country, the application of distance education, which started in Ankara University, Faculty of Law for the first time in 1956, continued with the decision to start an open university in 1978 and continued with the establishment of an Open Education Faculty in Anadolu University in 1981. Again in 1981, television education started with the cooperation of Anadolu University and TRT. In 1992, an open education high school was established under the Republic of Turkey's Ministry of National Education (Bozkurt, 2017, p. 88). The main purpose of distance education is to provide the opportunity of education to individuals under equal conditions.

In the literature, it was determined that the concept of distance education was evaluated together with online education, electronic education and computer-based education. Distance education is a superior concept encompassing computer-based education, on-line education and electronic education. This relationship is shown as follows:

Image 1. Subsets of distance learning (Urdan and Weggen, 2000, p. 9)

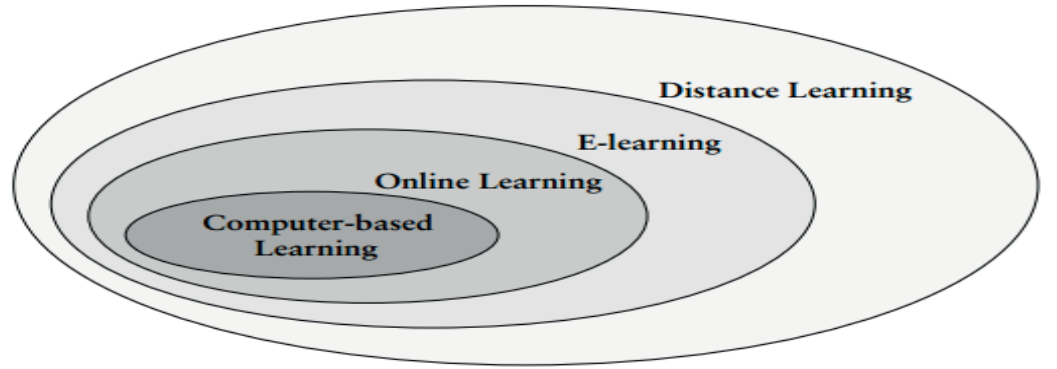

As the Figure shows, computer-based education makes up the foundation of the distance, electronic and on-line education, which are related with each other. According to Çukadar and Çelik (2003, p. 34) distance education and/or training practice is carried out by various methods. These are;

- $\quad$ Letter

- Radio and Television

- Computer and internet

- Informatics technologies

According to Peraya (2002) changes have occurred in the distance education methods and/ or techniques due to various reasons. These are; 
- The economical and social contexts have changed,

- The number of unemployed workers is increasing and all they need to be retrained,

- Knowledge has become one of the most important economic forces (forces productives),

- Knowledge is rapidly expanding and its life time becomes increasingly shorter,

- To survive in the market, companies need to change, to train and retrain their employees,

- Investing in the human resources seems to be the only way for a sustainable development.

\section{Libraries in Distance Education and the Roles of Libraries}

Libraries fulfill the information needs of users through their printed and electronic resources and the services they provide are based on these resources and at the same time, they contribute to user learning. Learning is one of the most significant determinant ensure change in the life of individuals. Individuals carry out their learning process in two ways; through formal and informal texts. Educational institutions are crucial for providing formal education. Libraries are the most important organizations that support formal education for their information resources and the services they provide. Users Access information resources located in libraries allow people to carry out their learning activity and meet their various needs. At this point, libraries are the most important supporters of educational institutions due to the fact that they provide formal education practices for users by arranging various educational programs to ensure the efficient use of the information resources and services. Hence, today libraries and information centers put an intense effort into providing the information needed by users, implementing innovations in information technology in their institutions and making the required changes in their service-understanding.

For example, the Committee of Standards of American Library Association stated that library resources and services must be provided for equally no matter where the academicians and students are. According to Lebowitz (1997, p. 304) again, in 1990 Howard Simmons, the representative of Middle States Accreditation Association said that there cannot be a difference in the quality of library services for the students present in the campus or distance learning students.

The establishment of library services and providing them with modern communication tools is necessary for equal opportunity in education, lifelong education and improving educational quality. One of the organizations to fulfill this requirement is the library. Students who participate in distance education need information resources as those who were educated 
by the traditional approach in a similar way although the processes, methods, techniques and tools of the traditional and distance education are not the same. However, libraries should meet the requirements needed to adapt to distance learning due to the fact that nowadays distance education is the trend of learning.

Librarians should keep in mind that one of the duties of libraries is to contribute to education when they design their information resources and services within the framework of their education. For this purpose, librarians must support both face-to-face education and distance education by making arrangements supporting formal education and contributing to the education of the individuals. Hence, the opportunities presented to information services especially by information and communication technologies today require librarians to act like educators.

\section{Methodology, Findings and Evaluation}

Descriptive survey method was used in the research. "A descriptive survey attempts to establish the range and distribution of some social characteristics, such as education or training, occupation, and location, and to discover how these characteristics may be related to certain behavior patterns or attitudes" (Sharp, 1981, p. 54). This study used a survey as the data collection technique to determine the assessments of the Department of Information and Records Management students in Atatürk University, Faculty of Letters about the use of distance education tools.

In this context, 400 students enrolled at the department were accepted as the population and 192 students were accepted as the sampling group by using the simple random sampling method. Based on this, 55 students answered the survey questions and the data were assessed in a $90 \%$ confidence interval and with $10.31 \%$ margin of error. The data obtained were analyzed with the SPSS 22.0 program.

Various questions were asked to the students in the survey to determine their knowledge levels about the distance education concept. Some of these questions were on daily internet connection times, mobile technology use, purposes of mobile technology use, whether they had knowledge about the mobile learning concept, and whether they received distance education in the universities that they are enrolled in and/or in another university. According to the results of the research, the general information (age, gender, etc.) of the students participating in the survey is included in the first section. The age information of the participants is presented in Table 1 below. 
Table 1. Age of participants

\begin{tabular}{|l|c|c|}
\hline Age & Frequency & $\mathbf{\%}$ \\
\hline $17-21$ & 24 & 43.63 \\
\hline $22-26$ & 29 & 52.72 \\
\hline $27-31$ & 2 & 3.63 \\
\hline Total & 55 & 99.98 \\
\hline
\end{tabular}

$24(43,63 \%)$ of the students participating in the study were in the 17-21 age range, 29 $(52,72 \%)$ in the $22-26$ age range, and $2(3,63 \%)$ in the $27-31$ age range. At the same time, 39 of the participants were female $(70,9 \%)$ and $16(29,1 \%)$ were male.

The students participating in the study were asked about the frequency of daily internet connection. In this context, responses were received from 55 students.

Table 2. Daily internet connection frequency

\begin{tabular}{|l|c|c|}
\hline Internet connection & Frequency & $\mathbf{\%}$ \\
\hline$>1$ & 4 & 7,3 \\
\hline $1-2$ hour & 7 & 12,7 \\
\hline $3-4$ hour & 18 & 32,7 \\
\hline $4+$ & 26 & 47,3 \\
\hline Total & 55 & 100 \\
\hline
\end{tabular}

According to Table 2, 26 (47.3\%) of the students connected to the internet for more than 4 hours a day, $18(32,7 \%)$ of them connected for 3-4 hours, 7 (12,7\%) of them connected for 1-2 hours and 4 (7,3\%) of them stated that they connected for less than 1 hour. Almost half of the students participating in the research use the internet for more than 4 hours a day.

Definitely, in order to evaluate a student's attitudes towards mobile learning and mobile learning tools, it is necessary to determine what mobile devices they have for this purpose, the students were asked what their mobile devices were. The data obtained are presented in Table 3.

Table 3. Mobile devices

\begin{tabular}{|l|c|c|}
\hline Mobile devices $^{\mathbf{1}}$ & Frequency & \% \\
\hline Laptop & 44 & 80 \\
\hline Tablet & 19 & 34,5 \\
\hline Smart phone & 53 & 96,36 \\
\hline
\end{tabular}

1 Students were allowed to mark more than one answer for this question. 
In the Table 3 presented above, the answers to the question of what mobile devices students have are examined. The students participating in the study were asked what mobile devices they use to be involved in the distance courses and/or programs.

Participants were allowed to tick more than one option. Accordingly, it was determined that 44 participants had a laptop, 19 participants had a tablet, and 53 participants had a smartphone.

The data obtained about the question of what devices were used to connect to distance education are presented in Table 4. According to the answers obtained, 16 of the participants stated that they connected to distance education environment via a laptop, 15 of them connected using a smartphone, and 1 of them connected using a tablet. In addition, 11 of the students accessed education remotely by using both a laptop and a smartphone, 5 of them accessed using only a laptop, 4 of them accessed using only a smartphone, and 1 of them accessed using a tablet. In other words, $76.6 \%$ of the students indicated that they received distance education service by means of laptop computers.

Table 4. Mobile devices used in distance education

\begin{tabular}{|l|c|c|}
\hline Mobile devices $^{2}$ & Frequency & \% \\
\hline Laptop & 16 & 76,6 \\
\hline Tablet & 1 & 4,8 \\
\hline Smart phone & 15 & 71,4 \\
\hline
\end{tabular}

$37(67,3 \%)$ of the students participating in the study stated that they had heard about the concept of mobile learning and/or distance education previously and $18(32,7 \%)$ stated that they heard the concept of mobile learning and/or distance education for the first time.

Image 2. Views on the concept of distance education

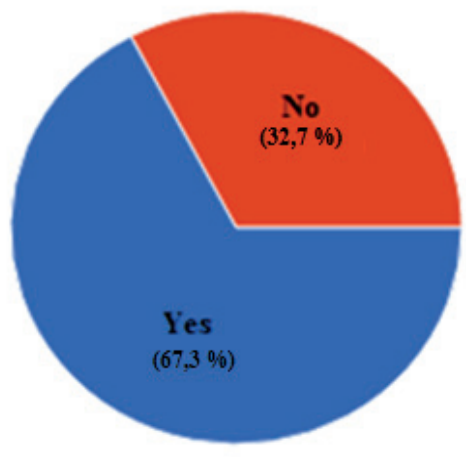

2 Students were allowed to mark more than one answer for this question. 
The question "Is distance education service provided in your university?" was asked to the students. While $50(90,9 \%)$ of the students stated that distance education was given, $5(9,1$ $\%$ ) of them answered that they received distance education. Considering that all universities provide distance education today, the statement of 5 students that there is no distance education program in their institutions is quite thought-provoking. In addition, $47(85,5 \%)$ of the students stated that they did not receive distance education service from a different institution, while 8 $(14,5 \%)$ stated that they received distance education service from another institution.

Image 3. Distance education provision

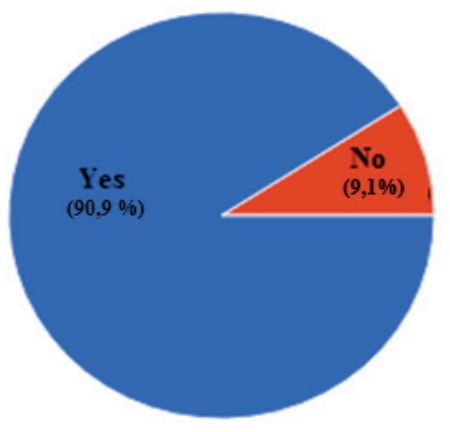

In the Table 5 below, students' views on the use of mobile devices in distance education are given.

Table 5. Use of mobile devices in distance education

\begin{tabular}{|l|c|c|}
\hline Use of mobile devices in distance education & Frequency & $\mathbf{\%}$ \\
\hline Must be used & 13 & 23,6 \\
\hline It will be useful if used & 39 & 70,9 \\
\hline Should not be used & 0 & 0 \\
\hline No idea & 3 & 5,4 \\
\hline Total & 55 & 99,9 \\
\hline
\end{tabular}

In this context, students were asked about their views on mobile devices and $70,9 \%$ of them stated that mobile devices should be used in distance education and 23,6 \% said that mobile devices should definitely be used.

In this part of the study, the students of the Department of Information and Records Management, who will be librarians and/or information experts in the future, were asked how the distance education tools affect information centers and librarians professionally, and the data obtained are presented below. The students were asked in which setting they preferred to use information resources. According to this, $67,3 \%$ of the students indicated that they 
used information resources in both the printed and electronic setting to access information, $30,9 \%$ used information sources in only the electronic setting and 1,8\% indicated that they used information resources in the printed setting. The collected data demonstrate that distance education tools should be used frequently in libraries and/or information centers because even the Department of Information and Records Management students, who are considered to play a role in the efficient and effective use of said tools in information centers (such as e-class resources, etc.) where distance education tools are used, need information and/or information sources in the electronic setting.

The students were asked about the role of information centers and/or libraries in the use of distance education and distance education tools. Reference services provided to the students who receive distance education service in information centers and/or libraries are as important as the reference services that the students in formal education receive. Therefore, the Department of Information and Records Management students who are to provide advisory services in the future were asked what reference services need to be provided to the students receiving distance education. According to this, the teaching of the function of the on-line library catalogue and how it needs to be used for information access turned out to be the most preferred advisory service $(81,8 \%)$ followed by, the electronic database service $(65,5 \%)$, electronic books $(54,5 \%)$ and web-based textbook resources $(50,9 \%)$.

The students were asked how the quality and efficient use of the distance education tools by information centers will affect the role of information centers in the future. The data obtained from the research are presented in Table 6.

Table 6. How the quality and efficient use of the distance education tools by information centers will affect the role of information centers in the future

\begin{tabular}{|l|l|c|c|}
\hline \multicolumn{1}{|l|}{ Role of information centers } & Frequency & \% \\
\hline \multirow{4}{*}{ Positive } & Retrieval to reliable information & \multirow{3}{*}{30} & \multirow{2}{*}{83,33} \\
\cline { 2 - 2 } & Quick and effective retrieval to information & & \\
\cline { 2 - 2 } & Increased use of information centers & \multirow{2}{*}{6} & \multirow{2}{*}{16,67} \\
\cline { 2 - 2 } & İ Increased demand of users for information services & \\
\cline { 2 - 3 } & Increase in the number of users & & \\
\hline \multirow{3}{*}{ Negative } & Reduce the number of users & & \\
\cline { 2 - 3 } & Digitalization concern of services & 36 & 100 \\
\cline { 2 - 3 } & $\begin{array}{l}\text { Reduced need for information professionals and/or librarians and } \\
\text { information centers }\end{array}$ & & \\
\hline Total & & & \\
\hline
\end{tabular}


It was determined that they thought information centers and/or libraries will gravitate to electronic resources rather than printed resources in the future which will quicken information access. In addition information centers will be digitalized gradually, and at the same time all of these developments will augment the usage of information centers. They thought that despite all of these favorable developments, the increase of information centers providing digital advisory services by fulfilling the requirements of distance education service will harm traditional information centers.

In the study scope, the students were also asked what qualifications are needed for librarians and/or information experts to make use of distance education tools in efficient and effective ways in information centers

Table 7. Efficient and effective use of distance education tools by information centers necessitates owning of what type of gear by librarians and/or information experts

\begin{tabular}{|l|c|c|}
\hline Type of gear & Frequency & $\%$ \\
\hline Competence in providing e-reference services & 5 & 14,70 \\
\hline Have technological competence & 22 & 64,70 \\
\hline Increasing foreign language knowledge & 3 & 8,82 \\
\hline The need for a practical training during the under graduate education & 2 & 5,89 \\
\hline Social media usage competence for the promotion of services & 2 & 5,89 \\
\hline Total & 34 & 100 \\
\hline
\end{tabular}

Based on the acquired data, it was determined that the most important qualification that the Department of Information and Records Management students must possess was the ability to manage information technologies Furthermore, the requirement for high e-advisory service provision skill was another element determined by the students. The students mentioned the lack of applied training in the Department of Information and Records Management and requested a solution for correcting the aforementioned deficiency. They also stated that social media usage skills should be developed in the promotion of educational tools and information services in the distance education process.

\section{RESULTS}

It was emphasized that the students who are going to be information experts in the future should be good information literates considering the yields of the information literacy concept, which is accepted as an umbrella term including technology literacy and internet literacy, etc., and based on this, it was indicated that the individuals who provide services need to have adequate skills to help improve their education to become information literate. 
According to the answers received from the students, $37 \%$ of the students think that the program they are studying is suitable for distance education. In addition, $33.3 \%$ of them stated that they do not have any idea whether the program they are studying is suitable for distance education. This situation is also in line with the view that the number of applied courses in departments should be high, which is expressed in the answer to the question of what kind of tools are required by information centers, and what kind of tools should be owned by librarians and/or information specialists.

One of the most common views is that an information center should offer reference services and/or services for distance education users, and should first provide services for the use of the online library catalog and databases, as well as providing a more concentrated service about web-based course use. Achieving the equal opportunity of distance education recipients with formal education is undoubtedly possible with access to information and information resources under the same conditions. For this reason, the opinions of the students of the Department of Information and Records Management who will provide services on this subject in the future are very important.

In the university where the students included in the study are located, the students stated that some of the counseling services (30.9\%) were offered face to face. Even though the rate of counseling services provided in electronic environment is high, it can be said that it would be appropriate to make face-to-face counseling services suitable for the electronic environment, considering that distance education students should also receive all counseling services However, in such a case, the thought that the need for information experts will decrease due to the prediction that the students of the Information and Records Management department will not be needed physically, makes the students nervous in terms of employment.

Effective use of distance education tools by information centers will undoubtedly affect information centers positively. The most important of these positive effects is the increase in the use of information centers. It will also increase the demand for information services. In addition, users can access information faster and more accurate information.

As evidenced by today's pandemic conditions, information experts are as important as educators in distance education. Librarians, just like educators, provide the students with remote services by supplying online information resources and facilities which are needed within the scope of distance courses. For this reason, first of all, the students of the Department of Information and Records Management should be capable of using the distance education tools very well.

In addition, they must be able to access remote education from any environment and be able to access any tool needed. A librarian and/or information specialist who uses distance 
education tools in accordance with the technology available on that day will also increase the use of the information center and at the same time ensure that the users access the right information at the right time. The cooperation between the Department of Information and Records Management and the departments of education sciences will undoubtedly be very meaningful for students who will receive distance education services.

Peer-review: Externally peer-reviewed.

Conflict of Interest: The author has no conflict of interest to declare.

Grant Support: The author declared that this study has received no financial support.

\section{References}

Çukadar, S., \& Çelik, S. (2003). Internete dayalı uzaktan öğretim ve üniversite kütüphaneleri. Doğuş Üniversitesi Dergisi, 4(1), 31-42.

Kırık, A. L. (2014). Uzaktan eğitimin tarihsel gelişimi ve Türkiye'deki durumu. Marmara İletişim Dergisi, 21, 73-94.

Lebowitz, G. (1997). Library services to distant students: An equity issue. The Journal of Academic Librarianship, 23(4), 303-308.

Peraya, Daniel. (2002). Distance education and the WWW. Education at a Distance, 9(7), 20-23.

Sharp, D. (1981). Descriptive survey. Marilyn Zurmuehlen Working Papers in Art Education, 15, 54-63.

Şenay, V., Yılmaz, M., Şenay, B. A., \& Güneş, A. (2015). A Study on the attitudes of prospective science teachers towards the effects of mobile applications and information services in distance education. Qualitative \& Quantitative Methods in Libraries,4(4). http://www.qqml.net/papers/December_2015_Issue/442QQML_ Journal_2015_VolkanSenayetal_749-753.pdf

Tang, Y. (2013). Distance education librarians in the United States: A study of job announcements. The Journal of Academic Librarianship, 39(6), 500-505.

Urdan, T. A., \& Weggen, C. C. (2000). Corporate-learning: Exploring a new frontier. http://cumincad.scix. net/cgibin/works/Show\&_id=caadria2010_000\&sort=DEFAULT\&search=series:caadria/Show?2c7d 